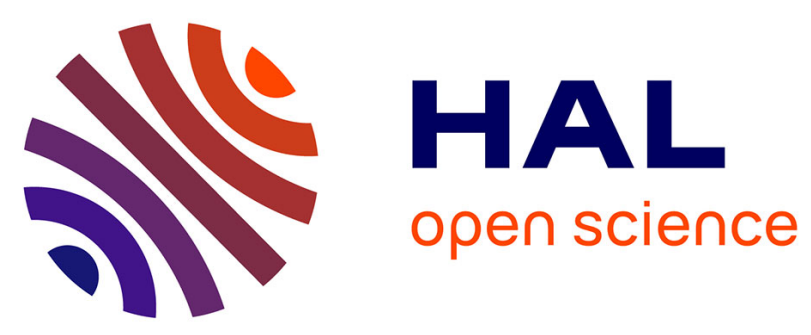

\title{
Association between dietary patterns reflecting one-carbon metabolism nutrients intake before pregnancy and placental DNA methylation
}

Marion Lecorguillé, Marie-Aline Charles, Johanna Lepeule, Sandrine Lioret, Blandine de Lauzon-Guillain, Anne Forhan, Jörg Tost, Matthew Suderman, Barbara Heude

\section{To cite this version:}

Marion Lecorguillé, Marie-Aline Charles, Johanna Lepeule, Sandrine Lioret, Blandine de LauzonGuillain, et al.. Association between dietary patterns reflecting one-carbon metabolism nutrients intake before pregnancy and placental DNA methylation. Epigenetics, 2021, 17 (7), pp.715-730. 10.1080/15592294.2021.1957575 . hal-03347084

\section{HAL Id: hal-03347084 \\ https://hal.science/hal-03347084}

Submitted on 16 Sep 2021

HAL is a multi-disciplinary open access archive for the deposit and dissemination of scientific research documents, whether they are published or not. The documents may come from teaching and research institutions in France or abroad, or from public or private research centers.
L'archive ouverte pluridisciplinaire HAL, est destinée au dépôt et à la diffusion de documents scientifiques de niveau recherche, publiés ou non, émanant des établissements d'enseignement et de recherche français ou étrangers, des laboratoires publics ou privés.

\section{(ㅇ)(1) $\$$}

Distributed under a Creative Commons Attribution - NonCommercial - NoDerivatives $\mid 4.0$ 


\section{Association Between Dietary Patterns Reflecting One- \\ Carbon Metabolism Nutrients Intake Before Pregnancy and Placental DNA Methylation}

Short title: OCM nutrients intake and placental DNA methylation

Marion Lecorguillé ${ }^{1 *}$, Marie-Aline Charles ${ }^{1,2}$, Johanna Lepeule ${ }^{3}$, Sandrine Lioret ${ }^{1}$,

Blandine de Lauzon-Guillain ${ }^{1}$, Anne Forhan ${ }^{1}$, Jörg Tost ${ }^{4}$, Matthew Suderman ${ }^{5 \dagger}$, and

Barbara Heude ${ }^{1 \dagger}$

1 Université de Paris, CRESS, INSERM, INRAE, Paris, France ;

2 Ined, Inserm, EFS, UMS Elfe, 93322 Aubervilliers, France;

3 Inserm, CNRS, Team of Environmental Epidemiology Applied to Reproduction and Respiratory Health, IAB, Université Grenoble Alpes, Grenoble, France;

4 Laboratory for Epigenetics and Environment, Centre National de Recherche en Génomique Humaine, CEA - Institut de Biologie François Jacob, Evry, France;

5 MRC Integrative Epidemiology Unit, Population Health Sciences, Bristol Medical

School, University of Bristol, Bristol, UK

* Correspondence:marion.lecorguille@inserm.fr

$\dagger$ These authors are joint senior authors on this work.

Grants: Marion Lecorguillé received a scholarship from the Paris Descartes University and the EHESP School of Public Health (France) for this work. 


\section{ABSTRACT}

Background: The preconception period represents an important window for fetal and epigenetic programming. Some micronutrients (B vitamins, choline, betaine, methionine) implicated in one-carbon metabolism (OCM) are essential for major epigenetic processes that take place in early pregnancy. However, few studies have evaluated the implication of the micronutrients in placental DNA methylation.

Objective: We investigated whether intake of OCM nutrients in the year before pregnancy was associated with placental DNA methylation in the EDEN mother-child cohort.

Design: Maternal dietary intake was assessed with a food-frequency questionnaire. Three dietary patterns, "varied and balanced diet", "vegetarian tendency", and "bread and starchy food", were used to characterize maternal OCM dietary intake. The Illumina Infinium HumanMethylation450 BeadChip was used to measure placental DNA methylation of 573 women included in the analyses. We evaluated the association of dietary patterns with global DNA methylation. Then, we conducted an agnostic epigenome-wide association study (EWAS) and investigated differentially methylated regions (DMRs) associated with each dietary pattern.

Results: We found no significant association between the three dietary patterns and global DNA methylation or individual CpG sites. DMR analyses highlighted associations between the "varied and balanced" or "vegetarian tendency" pattern and DMRs located at genes previously implicated in functions essential for embryonic development, such as neurodevelopment. The "bread and starchy food" pattern was associated with regions related to genes whose functions involve various metabolic and cell synthesis-related processes.

Conclusions: In mainly well-nourished French women without major deficiencies, OCM intake before pregnancy was not associated with major variation in DNA methylation.

Keywords: epigenetics; birth cohort; methyl-donors; dietary patterns; maternal diet; preconception period; global DNA methylation; placental DNA methylation; epigenome-wide association study. 


\section{INTRODUCTION}

The preconception period represents an important critical window for fetal and epigenetic programming (1). Epigenetics is defined as the study of the mechanisms that regulate gene expression without altered DNA sequence and appears to be particularly sensitive to environmental exposures during the early development $(1,2)$. Micronutrients implicated in one-carbon metabolism (OCM) deserve special attention because the OCM cycle supports multiple physiological processes essential for human development, including DNA methylation (3). The latter depends upon the supply of dietary OCM nutrients, which are necessary to establish methylation patterns during embryogenesis and maintain them during cell proliferation (1). OCM nutrients are carriers, methyl-group donors (e.g., folates, choline, betaine, methionine), and cofactors of enzymes involved in the transfer reactions of methyl groups to DNA (namely vitamins B2, B6, and B12) (3).

In humans, a few studies have evaluated the association between dietary intake of OCM nutrients and DNA methylation in children. In Gambia, a study evaluated the association between OCM micronutrient periconceptional status, assessed in maternal plasma, and DNA methylation at metastable epialleles, measured from lymphocytes and hair follicles in infants postnatally. Infants conceived during the dry and wet seasons (associated with significant seasonal nutritional variations) had different levels of DNA methylation at a number of sites, which were correlated with micronutrient status (4). Another study reported maternal dietary and supplemental intake of methyl-group donors (folate, betaine, folic acid) in the preconception period associated with buccal epithelial-cell DNA methylation in 6-month-old infants. The identified genes were related to child growth, metabolism and appetite (5). A recent randomized controlled trial showed folic acid supplementation in late pregnancy associated with methylation of a region upstream of the imprinting controller ZFP57 in cord blood (6). 
Adequate micronutrient intake is necessary to support placenta homeostasis and development (7). A few studies have investigated the role of OCM nutrients in DNA methylation variation in placental tissue. Two studies evaluated associations between choline intake or folic acid supplementation during pregnancy and placental DNA methylation by using a gene candidate approach but with a small sample size $(8,9)$. Exposure to an inappropriate maternal nutritional environment in the preconception period could also result in placental epigenetic changes, including changes in DNA methylation levels. The early waves of demethylation and de novo methylation that occur after fertilization affect both the epiblast which develops into the embryo, and the trophoblast, which develops into the placenta (10). Nevertheless, it is still unclear to what extent the maternal intake of OCM nutrients might affect placental DNA methylation.

We hypothesized that maternal OCM nutrient intake in the preconception period, more specifically during the year before pregnancy, could affect placental function by changing DNA methylation at an early stage in placental development. The purpose of our study was to examine whether dietary patterns which characterize the variability of pre-pregnancy intake of micronutrients involved in the one-carbon metabolism process (B vitamins, methionine, choline, and betaine) were associated with placenta DNA methylation at delivery in the French EDEN mother-child cohort. As previously described in a recent publication (11), we found that three dietary patterns explained the main variability of OCM nutrient intake before pregnancy, in women from the EDEN study: the "varied and balanced diet," "vegetarian tendency," "bread and starchy food" patterns. Our objective was exploratory and to assess how the different dietary patterns reflecting availability of OCM nutrients may influence both global methylation and specific genes. We first assessed the association of dietary pattern with global DNA methylation by using two proxies: Alu elements and long interspersed nucleotide elements (LINE-1). Then, we investigated DNA methylation associations with 
each dietary pattern by using an epigenome-wide approach at both the single- $\mathrm{CpG}$ site and regional levels.

\section{MATERIALS AND METHODS}

\section{Study}

The EDEN mother-child study is a prospective cohort that aimed to evaluate the early, preand post-natal determinants of child health and development (12) (see Supporting information, data availability). Study participation was proposed to all women visiting the prenatal clinic before 24 weeks' gestation. Between 2003 and 2006, 2002 (53\%) pregnant women aged 18 to 45 years old were recruited in two centres: Nancy and Poitiers hospitals. Exclusion criteria were multiple pregnancies, known diabetes before pregnancy, French illiteracy or planning to move out of the region within the next 3 years. All women gave their informed consent for inclusion before participation in the study. The study received approval from the ethics committee of Kremlin Bicêtre Hospital (02-70) and the Commission Nationale de l'Informatique et des Libertés, the French data privacy institution.

\section{Dietary data and other information collected during pregnancy}

The diet of women during the year before pregnancy was assessed retrospectively at inclusion (before 28 weeks' gestation; 15 weeks on average) by using a validated food-frequency questionnaire (13). A food composition database was not available to estimate the direct intake of some nutrients of interest (methionine, choline and betaine), so we used different sources to establish a food composition database and calculated individual nutrient intake following a methodology that we previously described (11). Three dietary patterns — "varied and balanced", "vegetarian tendency", and "bread and starchy food" — were identified using the reduced rank regression method to characterize OCM micronutrient intake (folates, 
choline, betaine, methionine, vitamins B2, B6, B12) in the year before pregnancy (14). The three patterns explained 58\% of the variability in OCM nutrient intake. For each woman, a score was calculated for each dietary pattern. The "varied and balanced diet" pattern was characterized by positive coefficients for the main OCM micronutrients, but lower coefficient for betaine. The "vegetarian tendency" pattern was characterized by high coefficients for vitamin B6, B9 and betaine to the detriment of other nutrients such as vitamin B12, choline, and methionine. The "bread and starchy food" pattern was mainly characterized by a high coefficient for betaine and negative coefficients for vitamins B2, B6, and B9 (11). The main characteristics of the patterns are presented in Table 1. Information on dietary supplementation in the 3 months before and during pregnancy was also collected by maternal self-completed questionnaires as consumption of mixed multivitamins/minerals or use of single micronutrients, among which we had information for vitamins B2, B6 and B9 (folic acid) as another source of OCM nutrient intake (11). This variable was defined in four categories: no supplementation, supplementation only before pregnancy, supplementation only during pregnancy, and supplementation before and during pregnancy.

Sociodemographic and pregnancy information were recorded by interviews with the mothers at 6 months of pregnancy and after delivery. We selected information about the recruitment centre (Poitiers vs Nancy), maternal age at delivery, BMI at conception (continuous) and maternal education level (at most lower secondary, upper secondary, postsecondary, or tertiary [bachelor's, master's, or doctoral level] classified according to the International Standard Classification of Education (15)). Smoking during pregnancy was classified into three groups to identify non-smokers, moderate, and heavy smokers (never, 1-9 cigarettes/day, $\geq 10$ cigarettes/day, respectively). 


\section{Placental DNA methylation assessment}

In total, 1301 placental samples were collected at delivery by a midwife or a technician of the study following a standardized protocol. Samples of approximately $5 \times 5 \mathrm{~mm}$ were taken from the centre of the placenta on the fetal side and were immediately frozen at $-80^{\circ} \mathrm{C}$. DNA from placental samples was extracted using the QIAsymphony instrument (Qiagen, Germany). DNA concentration was determined by Nanodrop measurement and fluorescent quantification using Picogreen. No sample was discarded due to low DNA concentration. The DNA quality control and epigenome analysis steps were performed by the Centre National de Recherche en Génomique Humaine (Evry, France). From the 2002 women, 1301 placenta samples were collected. Placenta samples could not be collected from all women, either due to absence of maternal consent, emergency for the EDEN woman or in care unit, and lack of time. Finally, due to budgetary restrictions, in total, 668 children had methylation data available for the study. The DNA samples were plated onto 96- or 48-well plates. A total of nine plates containing 64 chips were used. These plates were processed in four batches. The ratios for child sex (boy/girl) and recruitment centre (Poitiers/Nancy) were balanced for each BeadChip (16). Illumina's Infinium HumanMethylation450 BeadChips were used to evaluate the methylation status of 485,512 individual $\mathrm{CpG}$ sites in the placental samples (Illuminas, San Diego, CA, USA) (17). Raw signals from 450K BeadChips were extracted by using GenomeStudio v2011.1 (Illumina) (16). The DNA methylation level of each CpG was calculated as the ratio of the intensity of the normalized fluorescent signals of the methylated alleles to the sum of the methylated and unmethylated alleles.

We performed the data correction, quality control and normalization steps using the meffil $\mathrm{R}$ package as described by Min et al (18). In the quality control report, we checked variation due to technical artefacts, outliers, poor-quality samples and control probes, the ratio 
of unmethylated/methylated signal and extreme dye-bias. We excluded samples showing evidence of extreme dye-bias, probes targeting the sex chromosomes, probes with a bead count $<3$ in $>10 \%$ of samples as well as probes having a detection p-value greater than 0.01 in $>10 \%$ of samples, which led to 666 samples and $473362 \mathrm{CpG}$ sites measured for analyses.

Samples were then normalized by using functional normalization implemented in meffil. The main parameter of this method, the number of control probe principal components, was set to 15 . This was determined to be the number that maximizes the variance explained in the data (18). Probe intensity quantiles were then adjusted by removing variance encoded in the principal components and batch effects, as fixed and random effects, respectively. Finally, probe intensities were adjusted to conform to the adjusted quantiles. Methylation levels or $\beta$ values at $\mathrm{CpG}$ sites were estimated as ratios between normalized probe intensities representing methylated signals and the sum of methylated and unmethylated signals. Normalization reports were generated with meffil, evaluating associations between potential batch variables with normalized data. This approach identified batches and technical artefacts that were not completely resolved by using functional normalization and for which it was necessary to include the batch variable as covariate in the association studies.

Global methylation was also evaluated by measuring methylation in four $\mathrm{CpG}$ sites of repetitive $A l u$ and LINE-1 elements by using a previously published pyrosequencing methylation assay (19). More than one-third of DNA methylation is estimated to occur in repetitive elements. Methylation of these repetitive elements can serve as a surrogate marker for global genomic DNA methylation. We then used the median percentage methylation of the four CpG sites for analyses.

\section{Estimation of placental cellular composition}


Cellular composition of biological samples has been described as an important source of variability in epigenetic epidemiological studies. Placenta is a heterogeneous tissue comprising many cell types of differing development origins (20). DNA methylation levels are known to vary considerably between cell types, trophoblasts and mesenchymal components of the placenta (21). We used a method called reference-free adjustment for celltype composition (ReFACTor) that is based on principal component analysis (PCA) for correcting cell type heterogeneity (22). This method has been described as improving estimates of the cell-type composition, power and control for false discoveries in epigenomewide association study (EWAS) (22). One study described the maternal-fetal interface and cellular organization of placenta: seven cell types were identified on the fetal side (23). To be conservative, ReFACTor was used with default parameter settings, including the default number of cell types set to 10 . The algorithm is robust to the selection of this parameter set to 10 (22). To avoid ReFACTor generating components encoding sex differences, we included this variable as a covariate in the ReFACTor model.

\section{Statistical analyses}

\subsection{Descriptive analyses}

Characteristics of the population with available data on dietary patterns and placental DNA methylation are described with mean $\pm \mathrm{SD}$ and number $(\%)$.

\subsection{Global DNA methylation}

We examined the association between the three dietary patterns characterizing the variability in OCM micronutrient intake in the year before pregnancy ("varied and balanced", "vegetarian tendency" and "bread and starchy food"), OCM intake as supplements and the Alu and LINE-1 elements as proxies of overall methylation level. Associations were 
investigated by using robust linear regression, accounting for potential confounders and other adjustment factors identified from the literature: child sex, maternal age at delivery (continuous), study centre (Nancy/Poitiers), smoking during pregnancy (never, 1-9 cigarettes/day, $\geq 10$ cigarettes/day) and gestational age (continuous). We also adjusted for technical factors related to methylation measurements (batch effect) and estimated cell-type proportions. We also considered vitamin supplementation as an adjustment covariate. The interaction between OCM dietary patterns and maternal supplement intake before pregnancy (yes/no) was tested.

\subsection{EWAS}

Using the meffil package, we ran epigenome-wide analyses to identify $\mathrm{CpG}$ associations with each of the three dietary patterns. The dietary patterns are independent factors by construction and thus can be considered separately in the models. We performed analyses in three nested models, namely, a "no covariate model" (no adjustment), a "main model" (adjusted for child sex, study center, maternal age, smoking during pregnancy, gestational age, batch effect and cellular composition), and a "full model" (main model + adjustment for "surrogate variables" (SVA)). Indeed, in this last model, we used surrogate variable analysis to remove other potential sources of heterogeneity (24). Finally, we adjusted these analyses for vitamin supplementation before and during pregnancy. We used Bonferroni correction to derive a conservative $\mathrm{p}$-value threshold of $1.0 \times 10^{-7}(0.05 / 473362$ independent tests $)$ to determine sites showing strong evidence of association with our exposure, dietary patterns (25). To reduce the influence of potential outliers, we excluded data points below the 25th percentile minus 3 interquartile ranges or above the 75 th percentile plus 3 interquartile ranges for each probe. Analyses with additional adjustment for maternal education and parity were performed. Since these adjustments had no notable effect on associations with DNA 
methylation, either globally or at individual $\mathrm{CpG}$ sites, these factors were not considered in the full model.

As a supplementary analysis, we also tested the association between global DNA methylation and EWAS approaches with vitamin supplementation before and during pregnancy as an exposure, adjusted for the three dietary patterns in the "full" model. Statistical analyses were performed with R v3.6.2 and a Bonferroni-corrected $\mathrm{p}<0.05$ was considered significant.

\subsection{Differentially methylated regions}

Finally, we identified differentially methylated regions (DMRs) by using the $d m r f f$ package in $\mathrm{R}$, which identifies differentially methylated regions by combining EWAS summary statistics (from the "full model") for nearby CpGs (26). Significant differentially methylated regions were defined by the following criteria: 1) within one differentially methylated region, the distance between two neighboring probes is at most 500 base pairs; 2) the adjusted Bonferroni p-value associated with regions is $<0.05$, and 3 ) the regions were considered relevant if they included at least two $\mathrm{CpG}$ sites with beta values in the same direction and significantly different from 0 (nominal p-value <0.05). After identification of the DMR regions, the integrative gene database Genecards (27) and the encyclopedia of DNA elements ENCODE (28) were used to describe functions of identified genes or regions.

\section{Sample selection}

Among the 2002 women included in the EDEN study, 1301 placental samples were collected at birth and 668 methylome analyses were performed. After the previously described steps of quality control, normalisation and exclusion due to missing data in our exposure variable 
(dietary patterns), 573 women were included for analyses. The selection of the population is presented in Figure 1.

\section{RESULTS}

\section{Population characteristics}

The characteristics of the 573 women selected for analysis are summarized in Table 2. Mean maternal age was 29 years $( \pm 5)$ and about $30 \%$ of mothers smoked during pregnancy. Only $8.6 \%$ of women received vitamin and/or mineral supplementation both within the 3 months before pregnancy and during pregnancy.

\section{Global DNA methylation}

The mean (SD) percentage methylation was $16.2( \pm 1.0)$ for Alu and $26.1( \pm 1.9)$ for LINE-1. The estimated correlation between $A l u$ and LINE-1 sequences was 0.08 ( $\mathrm{p}=0.04)$. Associations between dietary patterns and global DNA methylation are shown in Table 3. We found no association between each dietary pattern and overall DNA methylation levels of Alu and LINE-1 elements, after adjustment for different confounding factors. We found no significant interactions between vitamin supplementation before pregnancy and dietary pattern scores in association with $A l u$ and LINE-1 methylation levels ( $\mathrm{p}_{\text {interaction }}>0.05$ ). Results were similar after adjustment for cell-type heterogeneity (Table 3). However, women who had vitamin supplementation before and during pregnancy showed higher methylation level on the $A l u$ repetitive element, with a positive regression coefficient of $0.40(p=0.005)$, which was not confirmed with the LINE-1 elements.

\section{EWAS results}


In the unadjusted model, the "varied and balanced" pattern was not associated with placental DNA methylation. Adjustment for potential confounding variables previously described ("full model") and cell-type estimation did not result in significant association between the dietary pattern scores and placental DNA methylation at any single site among the 557 mother-child pairs $\left(\mathrm{p}>1.0 \times 10^{-7}\right)$, as shown in the Manhattan plot (Figure 2). In the adjusted model, including surrogate variables, no significant $\mathrm{CpG}$ site was found. We also showed the results by using a quantile-quantile plot, showing the observed distribution of the p-values against the expected p-values under the null hypothesis of no association (Figure 3). Results were similar after adjusting for vitamin supplementation (Supplemental Figure 1). Similarly, we did not find evidence for an association between the other dietary patterns "vegetarian tendency" or "bread and starchy food" or vitamin supplementation (considered as a binary variable: supplemented or not) and placental DNA methylation (Supplemental Figure 2).

\section{Identification of differentially methylated regions}

The three dietary patterns were related to several DMRs, which are composed of CpG sites that are differentially methylated compared with the surrounding region. All DMRs contained at least two CpGs sites with a p-value $<0.05$. The "varied and balanced" pattern was significantly related to a DMR located on chromosome 3 and containing eight CpG sites (Table 4). This region was associated with the EPM2A Interacting Protein 1 (EPM2AIP1) and MutL Homolog 1 (MLH1) genes. The "vegetarian tendency" pattern was associated with two DMRs, located on chromosomes 19 and 11, containing respectively 6 and 5 CpG sites. DMRs were associated with Zinc Finger Protein 562 (ZNF562) and Fatty Acyl-CoA Reductase 1 (FARl) genes, respectively (Table 4). The "bread and starchy" pattern was related to three DMRs, located on chromosomes 10,8 and 5 and containing 5,8 , and $3 \mathrm{CpG}$ sites, respectively (Table 4). The three DMRs most strongly associated with the "bread and 
starchy" pattern were located near the Arsenite Methyltransferase (AS3MT) gene, Gasdermin D (GSDMD) gene and Solute Carrier Family 25 Member 46 (SLC25A46) gene respectively. After additional adjustment for vitamin supplementation, DMR analyses showed similar results for the "bread and starchy food" pattern. One additional region was found located near the Zinc Finger Protein 175 (ZNF175) gene (Table 5). For the "varied and balanced" pattern, we found an association with a DMR located on chromosome 9 and in a gene related to neurologic development, the Neural Proliferation, Differentiation and Control 1 (NPDC1) (Table 5). We found consistent association between the "vegetarian tendency" pattern and regions located on FARl. Additionally, we observed a tendency for an association with a DMR associated with the Delta-Like Canonical Notch Ligand 1 (DLL1) (Table 5).

\section{DISCUSSION}

To our knowledge, our study is the first epigenome-wide analysis of placental DNA methylation of dietary patterns characterizing OCM nutrient intake in the year before pregnancy for young women of childbearing age. We found no association between the different dietary patterns and global DNA methylation or individually analysed CpG sites in the placental tissue.

We previously showed in the EDEN cohort, that women with disadvantaged social status and possibly nutritional deficiencies were under-represented (11), which may explain in part why we did not find stronger associations of prenatal diet with placental DNA methylation. We evaluated the impact of pre-pregnancy maternal diet, which is relevant for early phenomena such as implantation and placenta development. However, other environmental and maternal factors during pregnancy affecting the placenta development may have masked the effects of earlier factors such as diet before pregnancy. Also, dietary effects on DNA methylation may be tissue-specific, and different results could be found in other 
tissues (cord blood, buccal cells) (20). Finally, little is known about the potentially complex association between methyl-group donors obtained by diet and global DNA methylation. One study evaluated the dietary intake of OCM nutrients (vitamin B12, betaine, choline and folate) during the periconception period and second trimester of pregnancy and found no association with LINE-1 methylation in cord blood (29). A randomized trial showed that children born from healthy mothers who received folic acid supplementation in the second and third trimesters of pregnancy had lower global LINE-1 methylation in cord blood than women who received a placebo (30). Another study of 24 pregnant women did not find an association between folic acid supplementation during pregnancy and LINE-1 methylation in cord blood (31).

However, we identified associations with several DMRs located on genes that could be implicated in functions related to development. The DMR associated with the "varied and balanced" pattern was located in EPM2AIP1 and MLH1 genes. EPM2AIP1 is a protein coding gene, involved in regulating glycogen synthesis and potential diseases associated with its function includes Lafora disease, a rare form of neurodegeneration and severe progressive epilepsy in adolescence $(32,33)$. MLH1 maintains the integrity of the genome by correcting mismatches that arise from DNA replication errors or damage (34). After adjustment for vitamin supplementation, the same pattern was associated with another DMR located in $N P D C 1$, involved in neural cell proliferation and differentiation (35). The strengths of associations with DMRs were relatively low with p-values close to the significance threshold, which explains why some DMRs were identified after additional covariate adjustment. The "varied and balanced" pattern is characterized by intake of the main micronutrients, such as choline and vitamin B9 (or folate), that are known to play an essential role in neurological development. A recent study reported a positive association between serum folate concentrations in adults aged above 65 years and increased DNA methylation on MLH1 (36). 
The "vegetarian tendency" pattern was associated with a DMR located in ZNF562, a gene that may be involved in transcriptional regulation, but few data have been published to date. Another DMR negatively associated with this pattern was located on FARl that encodes a protein required for lipid metabolism and fatty acid reduction. Mutations in this gene have been associated with neurological conditions such as severe intellectual disability, epilepsy, microcephaly, congenital cataracts, growth retardation and spasticity (37). After taking into account vitamin supplementation, we found another associated DMR located on DLL1, which is required for embryonic development, and plays a role in inter-cellular communication and cell fate decision processes in human lymphopoiesis (38). One study reported a novel differentially methylated region in placental samples from children with autism disorder, corresponding probably to a fetal brain enhancer near the DLL1 locus (39). DLL1 is also a transmembrane ligand protein of NOTCH receptors, which are involved in many aspects of vascular development and angiogenesis (40). Several studies have identified dysregulated expression of Notch family members in placentas with preeclampsia (40). As previously described, the "vegetarian tendency" pattern was characterized by a high intake of vitamin B9, which plays an important role in brain and placental development (41). One study reported low folate concentrations in early pregnancy associated with increased risk of preeclampsia (42).

The "bread and starchy food" pattern was associated with DMRs located in genes with varied functions, involved in arsenic metabolism (43), regulation of epithelial proliferation and cell differentiation in the skin and gastrointestinal tract, particularly as shown in one animal study focusing on the GSDMD gene (44). Finally, the SLC25A46 gene may play a role in mitochondria, and mutation of this gene results in neurodegenerative diseases (45). However, interpretation of these results must be considered with caution without additional information on the relation between the identified DMRs and related gene expression. 
Finally, vitamin supplementation before and during pregnancy was associated with significantly increased global DNA methylation as assessed by the Alu repetitive element. Women who initiated supplementation before pregnancy and followed this during pregnancy may have higher intake of OCM nutrients than their peers. High intake could result in increased methylation level, but this association was not confirmed with the LINE-1 elements. The correlation between the two proxies of global DNA methylation was lower than in other publications (0.08 vs > 0.20), which may explain this difference (46).

\section{$\underline{\text { Strengths and limitations }}$}

This study provides new insights into the characteristics of the diet of women of childbearing age before pregnancy in light of its contribution to the combined intake of OCM nutrients involved in DNA methylation. The placenta represents a relevant tissue, as the main organ of nutritional exchange between the mother and fetus during pregnancy. An important strength is that we had information on global DNA methylation (Alu and LINE-1 elements), which few studies have evaluated in placenta so far. Despite a lack of power that could explain the lack of an association in our analyses, particularly with individual $\mathrm{CpG}$ sites, the sample size is one of the largest in studies of placental DNA methylation (10).

However the placenta is a complex and heterogeneous tissue in its formation, and genes may be differentially expressed depending on the location of the sampled region (20), which may be a source of variability and thus noise for biological analyses. Moreover, even though we used ReFACTor method to account for cellular heterogeneity, we cannot exclude the possibility of residual confounding. One of the perspectives would be to compare results using the recently developed cell estimation references in the placenta (47).

Another limitation of nutritional epidemiology is the lack of precision in measuring diet in all its complexity. Information on food consumption was self-reported by women during 
pregnancy, which might be a source of declarative bias. Biomarkers of nutritional intake of OCM nutrients would be necessary to confirm these results. Unfortunately, these markers are not easy to collect during preconception unless specific studies have been set up during this period. One recent study meta-analysed results from two population-based birth cohort studies in Northern Europeans and reported significant associations between maternal plasma folate during pregnancy and DNA methylation in cord blood (48). We did not find any associations with the CpG sites linked to genes identified in this study, however we did not specifically investigate folate intake, and none of the dietary patterns was designed to proxy folate intake. Nutrients involved in the one-carbon metabolism pathway include a range of biological processes and complex interactions that need further investigation. Furthermore, we attempted to account for many potential confounders including technical factors and cell heterogeneity, but we cannot rule out confounding by genetics or other unmeasured environmental factors that may influence DNA methylation and dietary patterns (maternal stress, diabetes or food contaminant) (10). Finally, although we had information on vitamin supplementation, the data remain imprecise, which is a limitation of this study. We did not have information on the duration of supplementation or at which trimester during which women took supplements. Moreover, women may have had supplementation of one or more vitamins, so interpreting the individual effect of vitamin supplementation on DNA methylation is difficult. We did not attempt replication in this project because to our knowledge, there were no other studies with available data on the combined OCM nutrients intake before pregnancy and placental DNA methylation. However, replication in other cohorts with different nutritional intakes would be helpful to confirm these results.

\section{CONCLUSION}


In our sample of French women without major nutritional deficiencies, we did not find any major effect of OCM nutrient intake or vitamin supplementation on global DNA methylation or on CpG sites analysed separately. However, our results highlighted an association between the "varied and balanced" or "vegetarian tendency" dietary pattern and DMRs located in genes involved in various functions related to embryonic development, such as neurodevelopment. DMR analyses showed the "bread and starchy food" pattern associated with methylation of genes with various functions including metabolic or cell synthesis-related processes. Replication of these results in other studies is essential to evaluate the role of OCM nutrients in DNA methylation. Other studies of the functional implications of the genes potentially involved are necessary to understand how they may affect child development.

Author Contributions: All authors have read and agree to the published version of the manuscript. Conceptualization, M.L., M.S., B.H., M.A.C.; Methodology, M.L., M.S., B.d.L.- G., S.L., B.H., M.A.C.; Software, N/A; Validation, M.S., B.H., M.A.C.; Formal analysis, M.L., M.S., B.H.; Investigation, J.L., J.T., B.H., M.A.C.; Resources, J.L., J.T., M.S., B.H., M.A.C.; Data curation, M.L., M.S., A.F.; Writing-original draft preparation, M.L., M.S., B.H., M.A.C.; Writing-review and editing, M.L., S.L., B.d.L.- G., J.L., J.T., A.F., B.H., M.A.C., M.S.; Visualization, M.L.; Supervision, M.S., M.A.C., B.H.; Project administration, M.A.C., B.H.; Funding acquisition, M.L., M.A.C., B.H.

B.H., and M.S. contributed and supervised equally to the work of this article.

Funding statement: The EDEN study was supported by Foundation for Medical Research (FRM); National Agency for Research (ANR); National Institute for Research in Public health (IRESP: TGIR cohorte santé 2008 program); French Ministry of Health (DGS); French Ministry of Research; INSERM Bone and Joint Diseases National Research (PRO-A); and Human Nutrition National Research Programs; Paris-Sud University; Nestlé; French National 
Institute for Population Health Surveillance (InVS); French National Institute for Health Education (INPES); the European Union FP7 programs (FP7/2007-2013, HELIX, ESCAPE, ENRIECO, Medall projects); Diabetes National Research Program (through a collaboration with the French Association of Diabetic Patients); French Agency for Environmental Health Safety (now ANSES); Mutuelle Générale de l'Education Nationale; a complementary health insurance; French national agency for food security; and French-speaking association for the study of diabetes and metabolism (ALFEDIAM). The placental DNA measurements were funded by the Fondation de France (grant 2012-00031617 - 2012-00031593) and the ANR (ANR-13-CESA-0011-05). The scientific mobility of M Lecorguillé into the MRC Integrative Epidemiology Unit for a 4-month research stay was possible in part because of funding from the ALPHABET project. This latter project was supported by an award from the European Union's Horizon 2020 research and innovation program under the ERA-Net Cofund of the Joint Programming Initiative Healthy Diet for Healthy Life (JPI-HDHL) (http://www.healthydietforhealthylife.eu) (action no. 696295; Biomarkers for Nutrition and Health). M Lecorguillé received a doctoral mobility grant from the Public Health Doctoral Network from the EHESP (School for Higher Studies in Public Health) and the University of Paris Descartes. The funders had no role in the design and conduct of the study; in the management, analysis, and interpretation of the data; and preparation, review, or approval of the manuscript.

Acknowledgments: We thank Erwann De Gavelle and François Mariotti (UMR PNCA, AgroParisTech, INRAE, Université Paris-Saclay, F-75005 Paris, France) for their collaboration in developing the food composition database for the study. M Lecorguille thanks the Medical Research Council and Caroline Relton for the warm welcome during the research stay in Bristol. The authors thank the EDEN mother-child cohort study group, whose members are I. Annesi-Maesano, J.Y. Bernard, J. Botton, M.A. Charles, P. Dargent-Molina, 
B. de Lauzon-Guillain, P. Ducimetière, M. de Agostini, B. Foliguet, A. Forhan, X. Fritel, A. Germa, V. Goua, R. Hankard, B. Heude, M. Kaminski, B. Larroquey, N. Lelong, J. Lepeule, G. Magnin, L. Marchand, C. Nabet, F Pierre, R. Slama, M.J. Saurel-Cubizolles, M. Schweitzer, and O. Thiebaugeorges.

Conflicts of Interest: The authors declare no conflict of interest. 


\section{REFERENCES}

1. Dominguez-Salas P, Cox SE, Prentice AM, Hennig BJ, Moore SE. Maternal nutritional status, C(1) metabolism and offspring DNA methylation: a review of current evidence in human subjects. Proc Nutr Soc 2012;71:154-65.

2. Waterland RA, Michels KB. Epigenetic epidemiology of the developmental origins hypothesis. Annu Rev Nutr 2007;27:363-88.

3. Anderson OS, Sant KE, Dolinoy DC. Nutrition and epigenetics: An interplay of dietary methyl donors, one-carbon metabolism, and DNA methylation. J Nutr Biochem [Internet] 2012 [cited 2020 Apr 7];23:853-9. Available from: https://www.ncbi.nlm.nih.gov/pmc/articles/PMC3405985/

4. Dominguez-Salas P, Moore SE, Baker MS, Bergen AW, Cox SE, Dyer RA, Fulford AJ, Guan Y, Laritsky E, Silver MJ, et al. Maternal nutrition at conception modulates DNA methylation of human metastable epialleles. Nat Commun [Internet] 2014 [cited 2017 Apr 19];5. Available from: http://www.nature.com/doifinder/10.1038/ncomms4746

5. Pauwels S, Ghosh M, Duca RC, Bekaert B, Freson K, Huybrechts I, Langie SAS, Koppen G, Devlieger R, Godderis L. Maternal intake of methyl-group donors affects DNA methylation of metabolic genes in infants. Clin Epigenetics 2017;9:16.

6. Irwin RE, Thursby S-J, Ondičová M, Pentieva K, McNulty H, Richmond RC, Caffrey A, Lees-Murdock DJ, McLaughlin M, Cassidy T, et al. A randomized controlled trial of folic acid intervention in pregnancy highlights a putative methylation-regulated control element at ZFP57. Clin Epigenetics 2019;11:31.

7. Richard K, Holland O, Landers K, Vanderlelie JJ, Hofstee P, Cuffe JSM, Perkins AV. Review: Effects of maternal micronutrient supplementation on placental function. Placenta [Internet] 2017 [cited 2019 Jul 15];54:38-44. Available from: http://www.sciencedirect.com/science/article/pii/S0143400416306762

8. Tserga A, Binder AM, Michels KB. Impact of folic acid intake during pregnancy on genomic imprinting of IGF2/H19 and 1-carbon metabolism. FASEB J Off Publ Fed Am Soc Exp Biol 2017;31:5149-58.

9. Jiang X, Yan J, West AA, Perry CA, Malysheva OV, Devapatla S, Pressman E, Vermeylen F, Caudill MA. Maternal choline intake alters the epigenetic state of fetal cortisol-regulating genes in humans. FASEB J Off Publ Fed Am Soc Exp Biol 2012;26:3563-74.

10. Vlahos A, Mansell T, Saffery R, Novakovic B. Human placental methylome in the interplay of adverse placental health, environmental exposure, and pregnancy outcome. PLoS Genet [Internet] 2019 [cited 2020 May 10];15. Available from: https://www.ncbi.nlm.nih.gov/pmc/articles/PMC6675049/

11. Lecorguillé M, Lioret S, de Lauzon-Guillain B, de Gavelle E, Forhan A, Mariotti F, Charles M-A, Heude B. Association between Dietary Intake of One-Carbon Metabolism Nutrients in the Year before Pregnancy and Birth Anthropometry. Nutrients [Internet] 
2020 [cited 2020 Mar 31];12:838. Available from: https://www.mdpi.com/2072$6643 / 12 / 3 / 838$

12. Heude B, Forhan A, Slama R, Douhaud L, Bedel S, Saurel-Cubizolles M-J, Hankard R, Thiebaugeorges O, De Agostini M, Annesi-Maesano I, et al. Cohort Profile: The EDEN mother-child cohort on the prenatal and early postnatal determinants of child health and development. Int J Epidemiol 2016;45:353-63.

13. Deschamps V, de Lauzon-Guillain B, Lafay L, Borys J-M, Charles MA, Romon M. Reproducibility and relative validity of a food-frequency questionnaire among French adults and adolescents. Eur J Clin Nutr 2009;63:282-91.

14. Hoffmann K, Schulze MB, Schienkiewitz A, Nöthlings U, Boeing H. Application of a new statistical method to derive dietary patterns in nutritional epidemiology. Am J Epidemiol 2004;159:935-44.

15. International Standard Classification of Education (ISCED) [Internet]. 2017 [cited 2019 Feb 3]. Available from: http://uis.unesco.org/en/topic/international-standardclassification-education-isced

16. Abraham E, Rousseaux S, Agier L, Giorgis-Allemand L, Tost J, Galineau J, Hulin A, Siroux V, Vaiman D, Charles M-A, et al. Pregnancy exposure to atmospheric pollution and meteorological conditions and placental DNA methylation. Environ Int 2018;118:334-47.

17. Dedeurwaerder S, Defrance M, Bizet M, Calonne E, Bontempi G, Fuks F. A comprehensive overview of Infinium HumanMethylation450 data processing. Brief Bioinform [Internet] 2014 [cited 2020 May 13];15:929-41. Available from: https://www.ncbi.nlm.nih.gov/pmc/articles/PMC4239800/

18. Min JL, Hemani G, Davey Smith G, Relton C, Suderman M. Meffil: efficient normalization and analysis of very large DNA methylation datasets. Bioinforma Oxf Engl 2018;34:3983-9.

19. Yang AS, Estécio MRH, Doshi K, Kondo Y, Tajara EH, Issa J-PJ. A simple method for estimating global DNA methylation using bisulfite PCR of repetitive DNA elements. Nucleic Acids Res [Internet] 2004 [cited 2018 Jun 4];32:e38. Available from: https://www.ncbi.nlm.nih.gov/pmc/articles/PMC373427/

20. Hogg K, Price EM, Robinson WP. Improved reporting of DNA methylation data derived from studies of the human placenta. Epigenetics 2014;9:333-7.

21. Grigoriu A, Ferreira JC, Choufani S, Baczyk D, Kingdom J, Weksberg R. Cell specific patterns of methylation in the human placenta. Epigenetics 2011;6:368-79.

22. Rahmani E, Zaitlen N, Baran Y, Eng C, Hu D, Galanter J, Oh S, Burchard EG, Eskin E, Zou J, et al. Sparse PCA corrects for cell type heterogeneity in epigenome-wide association studies. Nat Methods 2016;13:443-5. 
23. Vento-Tormo R, Efremova M, Botting RA, Turco MY, Vento-Tormo M, Meyer KB, Park J-E, Stephenson E, Polański K, Goncalves A, et al. Single-cell reconstruction of the early maternal-fetal interface in humans. Nature 2018;563:347-53.

24. Leek JT, Storey JD. Capturing heterogeneity in gene expression studies by surrogate variable analysis. PLoS Genet 2007;3:1724-35.

25. Holm S. A Simple Sequentially Rejective Multiple Test Procedure. Scand J Stat [Internet] 1979 [cited 2020 May 15];6:65-70. Available from: https://www.jstor.org/stable/4615733

26. Suderman M, Staley JR, French R, Arathimos R, Simpkin A, Tilling K. dmrff: identifying differentially methylated regions efficiently with power and control. bioRxiv [Internet] 2018 [cited 2020 May 15];508556. Available from: https://www.biorxiv.org/content/10.1101/508556v1

27. Rebhan M, Chalifa-Caspi V, Prilusky J, Lancet D. GeneCards: a novel functional genomics compendium with automated data mining and query reformulation support. Bioinforma Oxf Engl 1998;14:656-64.

28. Davis CA, Hitz BC, Sloan CA, Chan ET, Davidson JM, Gabdank I, Hilton JA, Jain K, Baymuradov UK, Narayanan AK, et al. The Encyclopedia of DNA elements (ENCODE): data portal update. Nucleic Acids Res 2018;46:D794-801.

29. Boeke CE, Baccarelli A, Kleinman KP, Burris HH, Litonjua AA, Rifas-Shiman SL, Tarantini L, Gillman M. Gestational intake of methyl donors and global LINE-1 DNA methylation in maternal and cord blood: prospective results from a folate-replete population. Epigenetics 2012;7:253-60.

30. Caffrey A, Irwin RE, McNulty H, Strain JJ, Lees-Murdock DJ, McNulty BA, Ward M, Walsh CP, Pentieva K. Gene-specific DNA methylation in newborns in response to folic acid supplementation during the second and third trimesters of pregnancy: epigenetic analysis from a randomized controlled trial. Am J Clin Nutr 2018;107:566-75.

31. Fryer AA, Nafee TM, Ismail KMK, Carroll WD, Emes RD, Farrell WE. LINE-1 DNA methylation is inversely correlated with cord plasma homocysteine in man: A preliminary study. Epigenetics [Internet] 2009 [cited 2020 Jun 11];4:394-8. Available from: https://doi.org/10.4161/epi.4.6.9766

32. Ianzano L, Zhao XC, Minassian BA, Scherer SW. Identification of a novel protein interacting with laforin, the EPM2a progressive myoclonus epilepsy gene product. Genomics 2003;81:579-87.

33. Turnbull J, Tiberia E, Pereira S, Zhao X, Pencea N, Wheeler AL, Yu WQ, Ivovic A, Naranian T, Israelian N, et al. Deficiency of a Glycogen Synthase-associated Protein, Epm2aip1, Causes Decreased Glycogen Synthesis and Hepatic Insulin Resistance. J Biol Chem [Internet] 2013 [cited 2020 Jun 1];288:34627-37. Available from: https://www.ncbi.nlm.nih.gov/pmc/articles/PMC3843075/

34. Jun S-H, Kim TG, Ban C. DNA mismatch repair system. Classical and fresh roles. FEBS J 2006;273:1609-19. 
35. Qu X, Zhang C, Zhai Y, Xing G, Wei H, Yu Y, Wu S, He F. Characterization and tissue expression of a novel human gene npdc1. Gene 2001;264:37-44.

36. Sanchez H, Hossain MB, Lera L, Hirsch S, Albala C, Uauy R, Broberg K, Ronco AM. High levels of circulating folate concentrations are associated with DNA methylation of tumor suppressor and repair genes p16, MLH1, and MGMT in elderly Chileans. Clin Epigenetics [Internet] 2017 [cited 2020 Jun 1];9. Available from: https://www.ncbi.nlm.nih.gov/pmc/articles/PMC5525256/

37. Buchert R, Tawamie H, Smith C, Uebe S, Innes AM, Al Hallak B, Ekici AB, Sticht H, Schwarze B, Lamont RE, et al. A peroxisomal disorder of severe intellectual disability, epilepsy, and cataracts due to fatty acyl-CoA reductase 1 deficiency. Am J Hum Genet 2014;95:602-10.

38. Jaleco AC, Neves H, Hooijberg E, Gameiro P, Clode N, Haury M, Henrique D, Parreira L. Differential Effects of Notch Ligands Delta-1 and Jagged-1 in Human Lymphoid Differentiation. J Exp Med [Internet] 2001 [cited 2020 May 29];194:991-1002. Available from: https://www.ncbi.nlm.nih.gov/pmc/articles/PMC2193482/

39. Schroeder DI, Schmidt RJ, Crary-Dooley FK, Walker CK, Ozonoff S, Tancredi DJ, Hertz-Picciotto I, LaSalle JM. Placental methylome analysis from a prospective autism study. Mol Autism [Internet] 2016 [cited 2020 Jun 1];7. Available from: https://www.ncbi.nlm.nih.gov/pmc/articles/PMC5159983/

40. Shimanuki Y, Mitomi H, Fukumura Y, Makino S, Itakura A, Yao T, Takeda S. Alteration of Delta-like ligand 1 and Notch 1 receptor in various placental disorders with special reference to early onset preeclampsia. Hum Pathol [Internet] 2015 [cited 2020 Jun 1];46:1129-37. Available from: http://www.sciencedirect.com/science/article/pii/S0046817715001161

41. Morse NL. Benefits of Docosahexaenoic Acid, Folic Acid, Vitamin D and Iodine on Foetal and Infant Brain Development and Function Following Maternal Supplementation during Pregnancy and Lactation. Nutrients [Internet] 2012 [cited 2019 Oct 7];4:799-840. Available from: https://www.ncbi.nlm.nih.gov/pmc/articles/PMC3407995/

42. Bergen NE, Jaddoe VWV, Timmermans S, Hofman A, Lindemans J, Russcher H, Raat H, Steegers-Theunissen RPM, Steegers E a. P. Homocysteine and folate concentrations in early pregnancy and the risk of adverse pregnancy outcomes: the Generation R Study. BJOG Int J Obstet Gynaecol 2012;119:739-51.

43. Schläwicke Engström K, Nermell B, Concha G, Strömberg U, Vahter M, Broberg K. Arsenic metabolism is influenced by polymorphisms in genes involved in one-carbon metabolism and reduction reactions. Mutat Res Mol Mech Mutagen [Internet] 2009 [cited 2020 May 29];667:4-14. Available from: http://www.sciencedirect.com/science/article/pii/S0027510708001346

44. Tamura M, Tanaka S, Fujii T, Aoki A, Komiyama H, Ezawa K, Sumiyama K, Sagai T, Shiroishi T. Members of a novel gene family, Gsdm, are expressed exclusively in the epithelium of the skin and gastrointestinal tract in a highly tissue-specific manner. Genomics 2007;89:618-29. 
45. Charlesworth G, Balint B, Mencacci NE, Carr L, Wood NW, Bhatia KP. SLC25A46 mutations underlie progressive myoclonic ataxia with optic atrophy and neuropathy. Mov Disord Off J Mov Disord Soc 2016;31:1249-51.

46. Wilhelm-Benartzi CS, Houseman EA, Maccani MA, Poage GM, Koestler DC, Langevin SM, Gagne LA, Banister CE, Padbury JF, Marsit CJ. In Utero Exposures, Infant Growth, and DNA Methylation of Repetitive Elements and Developmentally Related Genes in Human Placenta. Environ Health Perspect [Internet] 2012 [cited 2020 Jun 15];120:296302. Available from: https://www.ncbi.nlm.nih.gov/pmc/articles/PMC3279448/

47. Yuan V, Hui D, Yin Y, Peñaherrera MS, Beristain AG, Robinson WP. Cell-specific characterization of the placental methylome. BMC Genomics 2021;22:6.

48. Joubert BR, den Dekker HT, Felix JF, Bohlin J, Ligthart S, Beckett E, Tiemeier H, van Meurs JB, Uitterlinden AG, Hofman A, et al. Maternal plasma folate impacts differential DNA methylation in an epigenome-wide meta-analysis of newborns. Nat Commun [Internet] 2016 [cited 2021 May 17];7. Available from: https://www.ncbi.nlm.nih.gov/pmc/articles/PMC4749955/ 
Table 1: Characteristics of the three dietary patterns resulting from the reduced rank regression method, described in details in (11)

\begin{tabular}{|c|c|c|c|}
\hline & Varied and balanced & Vegetarian tendency & Bread and starchy food \\
\hline High intake of main food groups* & $\begin{array}{c}\text { Low-fat milk, meat, liver, fish, eggs } \\
\text { and egg dishes, cereals, mixed } \\
\text { vegetables, chicory, leeks and } \\
\text { cabbage, and broccoli }\end{array}$ & $\begin{array}{c}\text { Fruits, chicory, mixed vegetables, } \\
\text { cereals, and bread }\end{array}$ & $\begin{array}{l}\text { Bread, sandwiches and rice, pasta } \\
\text { and other grains }\end{array}$ \\
\hline Low intake of food groups* & $\begin{array}{l}\text { Snacks and confectionery and sugar- } \\
\text { sweetened beverages }\end{array}$ & Meat and liver & $\begin{array}{c}\text { Low-fat milk, fruits, fruit juices, and } \\
\text { sugar-sweetened beverages }\end{array}$ \\
\hline \multicolumn{4}{|l|}{ Association with OCM nutrients ${ }^{2}$} \\
\hline Positive coefficient & B vitamins, choline, and methionine & B6 and B9 vitamins and betaine & Betaine \\
\hline
\end{tabular}

*High and low intake of main food groups with factor loading $\geq 0.20$.

${ }^{1}$ Explained variation in the overall nutrient variables from the reduced-rank regression

${ }^{2}$ Association of the nutrient variables with the three dietary patterns. 
Table 2: Characteristics of women selected for analysis $(\mathrm{N}=573)$

\begin{tabular}{|c|c|c|}
\hline Sociodemographic data & $\begin{array}{c}\text { Missing data } \\
\text { n (\%) }\end{array}$ & Population* \\
\hline Study centre & $0(0)$ & - \\
\hline Poitiers & & $251(44)$ \\
\hline Nancy & & $322(56)$ \\
\hline Maternal age (years) & $0(0)$ & $29.2 \pm 5$ \\
\hline Maternal education level & $3(0.5)$ & - \\
\hline Lower secondary school & & $151(26.5)$ \\
\hline Upper secondary school & & $100(17.5)$ \\
\hline Post-secondary & & $123(21.6)$ \\
\hline Tertiary & & $196(34.4)$ \\
\hline \multicolumn{3}{|l|}{ Pregnancy } \\
\hline Gestational age (weeks) & $0(0)$ & $39.3 \pm 1.5$ \\
\hline Primiparous & $1(0.15)$ & $258(45)$ \\
\hline Smoking during pregnancy & $16(2.8)$ & - \\
\hline No & & $390(70)$ \\
\hline 1-9 cigarettes/day & & $138(24.8)$ \\
\hline At least 10 cigarettes/day & & $29(5.2)$ \\
\hline Vitamin supplementation & $3(0.5)$ & \\
\hline No & & $339(59.5)$ \\
\hline Before pregnancy & & $53(9.3)$ \\
\hline During pregnancy & & $129(22.6)$ \\
\hline Before and during pregnancy & & $49(8.6)$ \\
\hline BMI at conception, $\mathrm{kg} / \mathrm{m}^{2}$ & $10(1.7)$ & $22.9 \pm 4.2$ \\
\hline Child sex & $0(0)$ & - \\
\hline Boy & & $302(52.7)$ \\
\hline Girl & & $271(47.3)$ \\
\hline
\end{tabular}

*Descriptive data $\mathrm{n}(\%)$ and mean \pm SD. BMI, body mass index 
Table 3: Association between dietary patterns or vitamin supplementation and global DNA methylation in different adjusted models

\begin{tabular}{|c|c|c|c|c|c|c|c|c|}
\hline \multirow[b]{2}{*}{ Exposure } & \multicolumn{4}{|c|}{$\begin{array}{c}\text { Alu } \\
(16.2 \pm 1.0) *\end{array}$} & \multicolumn{4}{|c|}{$\begin{array}{c}L I N E-1 \\
(26.1 \pm 1.9) *\end{array}$} \\
\hline & $\beta^{1}(\mathrm{SE})$ & P-value & $\beta^{2}(\mathrm{SE})$ & P-value & $\beta^{1}(\mathrm{SE})$ & P-value & $\beta^{2}(\mathrm{SE})$ & P-value \\
\hline Varied and balanced & $-0.02(0.03)$ & 0.60 & $-0.02(0.03)$ & 0.52 & $-0.10(0.07)$ & 0.16 & $-0.07(0.07)$ & 0.31 \\
\hline Vegetarian tendency & $0.02(0.04)$ & 0.69 & $0.03(0.04)$ & 0.50 & $-0.13(0.08)$ & 0.11 & $-0.10(0.08)$ & 0.18 \\
\hline \multicolumn{9}{|l|}{ Vitamin supplementation } \\
\hline No supplementation & Reference & & Reference & & Reference & & Reference & \\
\hline Before pregnancy only & $-0.14(0.14)$ & 0.29 & $-0.14(0.14)$ & 0.29 & $0.10(0.29)$ & 0.74 & $0.06(0.28)$ & 0.82 \\
\hline During pregnancy only & $0.15(0.09)$ & 0.11 & $0.16(0.09)$ & 0.08 & $0.18(0.20)$ & 0.37 & $0.23(0.20)$ & 0.24 \\
\hline
\end{tabular}

Median percentage of the four CpG sites in Alu and long interspersed nucleotide elements [LINE-1] as proxies of overall methylation level

Data are regression coefficients for an increase in one score unit for each dietary pattern.

*mean percentage methylation level

${ }^{1}$ Adjusted models for study center, maternal age, child sex, smoking during pregnancy, gestational age, batch effect and vitamin supplementation (model for dietary pattern), and adjusted mutually for the three dietary patterns (model for vitamin supplementation).

${ }^{2}$ Additional adjustment for estimated cellular composition.

$\mathrm{P}<0.05$. SE: standard error 
Table 4: Dietary patterns in the year before pregnancy and differentially methylated regions (DMRs) ${ }^{1}$ of placental DNA in the EDEN cohort

\begin{tabular}{|c|c|c|c|c|c|c|c|}
\hline Exposure & $\begin{array}{c}\text { Number of } \\
\text { CpG sites }\end{array}$ & Chr & Position & Gene(s) & CpG site & $\begin{array}{c}\text { DMR direction of } \\
\text { association and } \\
\text { individual CpG site } \\
\beta \text {-value }\end{array}$ & P-value ${ }^{3}$ \\
\hline \multirow[t]{9}{*}{$\begin{array}{l}\text { Varied and } \\
\text { balanced }\end{array}$} & 8 & Chr 3 & $\begin{array}{l}37034730- \\
37034956\end{array}$ & $\begin{array}{c}\text { EPM2AIP1, } \\
M L H 1\end{array}$ & & Positive & 0.003 \\
\hline & & & & & cg10769891 & 0.0002466 & 0.05 \\
\hline & & & & & $\operatorname{cg} 19132762$ & 0.0000365 & 0.81 \\
\hline & & & & & $\operatorname{cg} 23658326$ & 0.0001607 & 0.04 \\
\hline & & & & & $\operatorname{cg} 11600697$ & -0.0002116 & 0.49 \\
\hline & & & & & $\operatorname{cg} 21490561$ & -0.0001209 & 0.45 \\
\hline & & & & & $\operatorname{cg} 00893636$ & -0.0000941 & 0.68 \\
\hline & & & & & $\operatorname{cg} 03192963$ & 0.0000985 & 0.54 \\
\hline & & & & & $\operatorname{cg} 06791151$ & -0.0000509 & 0.58 \\
\hline \multirow[t]{13}{*}{$\begin{array}{l}\text { Vegetarian } \\
\text { tendency }\end{array}$} & 6 & Chr 19 & $\begin{array}{l}9785647- \\
9785919\end{array}$ & ZNF562 & & Positive & $4.610^{-18}$ \\
\hline & & & & & $\operatorname{cg} 10755961$ & 0.0005334 & 0.04 \\
\hline & & & & & $\operatorname{cg} 24874111$ & -0.0006368 & 0.09 \\
\hline & & & & & $\operatorname{cg} 18587364$ & -0.0003679 & 0.46 \\
\hline & & & & & cg20631204 & -0.0002906 & 0.40 \\
\hline & & & & & $\operatorname{cg} 14073063$ & 0.0001544 & 0.53 \\
\hline & & & & & $\operatorname{cg} 14308647$ & 0.0003846 & 0.03 \\
\hline & 5 & Chr 11 & $\begin{array}{l}13690122- \\
13690194\end{array}$ & FARI & & Negative & $9.5 .10^{-10}$ \\
\hline & & & & & cg02831587 & 0.0003768 & 0.04 \\
\hline & & & & & $\operatorname{cg} 26240185$ & -0.0000984 & 0.17 \\
\hline & & & & & cg03326059 & -0.0000360 & 0.49 \\
\hline & & & & & $\operatorname{cg} 10572969$ & -0.0000200 & 0.77 \\
\hline & & & & & cg24412501 & 0.0003739 & 0.04 \\
\hline
\end{tabular}




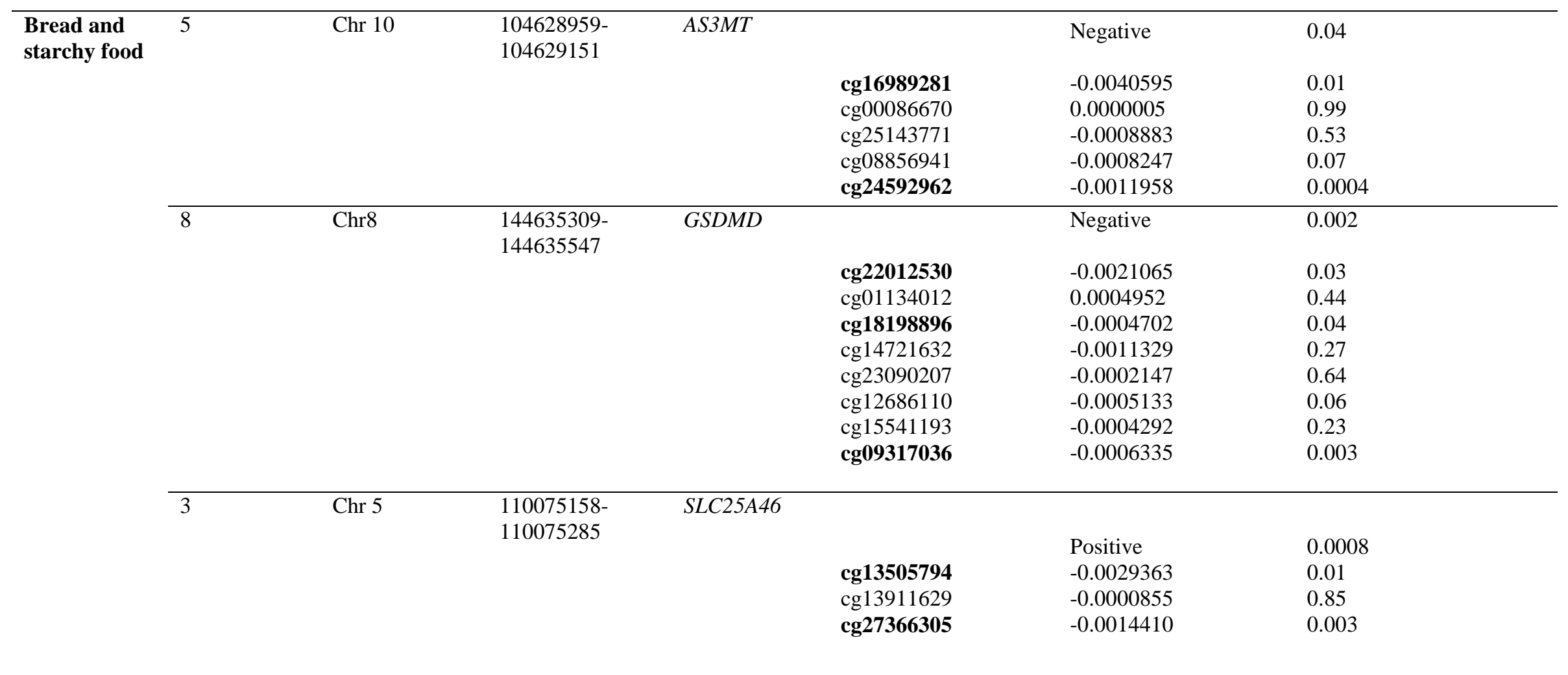

${ }^{1}$ DMRs determined with the use of $\operatorname{dmrff}(26)$. All models were adjusted for child sex, study center, maternal age, gestational age, smoking during pregnancy, batch effect, cell-type distribution estimated and SVA variables.

${ }^{2}$ Coefficient associated with DMR or direction of the association. $\beta$-value reported for individual CpG sites.

${ }^{3}$ Adjusted p-value associated with DMR and no-adjusted p-value for CpG sites. 
Table 5: Dietary patterns in the year before pregnancy and differentially methylated regions (DMRs) ${ }^{1}$ of placental DNA, after adjustment for vitamin supplementation

\begin{tabular}{|c|c|c|c|c|c|c|c|}
\hline Exposure & $\begin{array}{c}\text { Number of } \\
\text { CpG sites }\end{array}$ & Chr & Position & Gene & CpG site & $\begin{array}{c}\text { DMR direction of } \\
\text { association and } \\
\text { individual } \mathrm{CpG} \text { site } \beta \text { - } \\
\text { value }^{2}\end{array}$ & P-value ${ }^{3}$ \\
\hline \multirow[t]{4}{*}{$\begin{array}{l}\text { Varied and } \\
\text { balanced }\end{array}$} & 3 & Chr 9 & $\begin{array}{c}139940640- \\
139941067\end{array}$ & $N P D C 1$ & & Positive & 0.02 \\
\hline & & & & & $\operatorname{cg} 22952834$ & 0.0002152 & 0.031 \\
\hline & & & & & $\operatorname{cg} 12611723$ & 0.0014960 & 0.0001 \\
\hline & & & & & $\operatorname{cg} 17902858$ & 0.0010973 & 0.0004 \\
\hline \multirow[t]{16}{*}{$\begin{array}{l}\text { Vegetarian } \\
\text { tendency }\end{array}$} & 4 & Chr 6 & $\begin{array}{c}170599869- \\
170600060\end{array}$ & DLLI & & Negative & $5.3 .10^{-7}$ \\
\hline & & & & & $\operatorname{cg} 08273501$ & -0.0002168 & 0.31 \\
\hline & & & & & $\operatorname{cg} 12024311$ & -0.0000268 & 0.79 \\
\hline & & & & & $\operatorname{cg} 27139933$ & -0.0000134 & 0.97 \\
\hline & & & & & cg00474209 & 0.0012425 & 0.004 \\
\hline & 3 & Chr 6 & 170599826- & $D L L 1$ & & Negative & $7.0 .10^{-3}$ \\
\hline & & & 170599840 & & $\operatorname{cg03394401}$ & 0.0038978 & 0.008 \\
\hline & & & & & $\operatorname{cg} 14497851$ & -0.0000644 & 0.55 \\
\hline & & & & & $\operatorname{cg} 03815571$ & 0.0005043 & 0.40 \\
\hline & 2 & Chr 11 & $\begin{array}{l}13690122- \\
13690157\end{array}$ & FARI & & Negative & $3.7 .10^{-9}$ \\
\hline & & & & & $\operatorname{cg02831587}$ & 0.0003705 & 0.04 \\
\hline & & & & & g10572969 & -0.0001112 & 0.12 \\
\hline & 3 & Chr 11 & $\begin{array}{c}13690160- \\
13690194\end{array}$ & FARl & & Negative & $7.8 .10^{-3}$ \\
\hline & & & & & $\operatorname{cg} 03326059$ & -0.0000295 & 0.57 \\
\hline & & & & & $\operatorname{cg} 10572969$ & -0.0000240 & 0.73 \\
\hline & & & & & $\operatorname{cg} 24412501$ & 0.0003721 & 0.05 \\
\hline
\end{tabular}




\begin{tabular}{|c|c|c|c|c|c|c|c|}
\hline \multirow[t]{4}{*}{$\begin{array}{l}\text { Bread and } \\
\text { starchy food }\end{array}$} & 5 & Chr 10 & $\begin{array}{c}104628959- \\
104629151\end{array}$ & $A S 3 M T$ & $\begin{array}{c}\text { cg16989281 } \\
\operatorname{cg} 0086670 \\
\operatorname{cg} 25143771 \\
\operatorname{cg} 08856941 \\
\text { cg24592962 }\end{array}$ & $\begin{array}{c}\text { Negative } \\
-0.0040765 \\
0.0000536 \\
-0.0007242 \\
-0.0008231 \\
-0.0012140\end{array}$ & $\begin{array}{c}0.02 \\
0.01 \\
0.94 \\
0.61 \\
0.07 \\
0.0003\end{array}$ \\
\hline & 8 & Chr8 & $\begin{array}{c}144635309- \\
144635547\end{array}$ & $G S D M D$ & $\begin{array}{l}\text { cg22012530 } \\
\text { cg01134012 } \\
\text { cg18198896 } \\
\text { cg14721632 } \\
\text { cg23090207 } \\
\text { cg12686110 } \\
\text { cg15541193 } \\
\text { cg09317036 }\end{array}$ & $\begin{array}{c}\text { Negative } \\
-0.0020483 \\
0.0005035 \\
-0.0004714 \\
-0.0010857 \\
-0.0002096 \\
-0.0005028 \\
-0.0004105 \\
-0.0006211 \\
\end{array}$ & $\begin{array}{c}0.004 \\
0.03 \\
0.43 \\
0.04 \\
0.29 \\
0.65 \\
0.06 \\
0.25 \\
0.003 \\
\end{array}$ \\
\hline & 3 & Chr 5 & $\begin{array}{l}110075158- \\
110075285\end{array}$ & SLC25A46 & $\begin{array}{l}\text { cg13505794 } \\
\text { cg13911629 } \\
\text { cg27366305 }\end{array}$ & $\begin{array}{c}\text { Positive } \\
-0.0029720 \\
-0.0001567 \\
-0.0013743\end{array}$ & $\begin{array}{c}0.01 \\
0.01 \\
0.74 \\
0.006\end{array}$ \\
\hline & 4 & Chr 19 & $\begin{array}{c}52074293- \\
52074348\end{array}$ & ZNF175 & $\begin{array}{l}\text { cg18379413 } \\
\text { cg18708075 } \\
\text { cg26605406 } \\
\text { cg01382982 }\end{array}$ & $\begin{array}{c}\text { Positive } \\
0.0127613 \\
0.0129549 \\
0.0095819 \\
0.0075372\end{array}$ & $\begin{array}{c}0.006 \\
0.003 \\
0.02 \\
0.21 \\
0.26\end{array}$ \\
\hline
\end{tabular}

${ }^{1}$ DMRs determined with the use of dmrff (26). All models were adjusted for child sex, study center, maternal age, gestational age, smoking during pregnancy, batch effect, cell-type distribution estimated, surrogate variable analysis variables and vitamin supplementation.

${ }^{2}$ Coefficient associated with DMR or direction of the association. $\beta$-value reported for individual CpG sites.

${ }^{3}$ Adjusted p-value associated with DMR and no-adjusted p-value for CpG sites. 


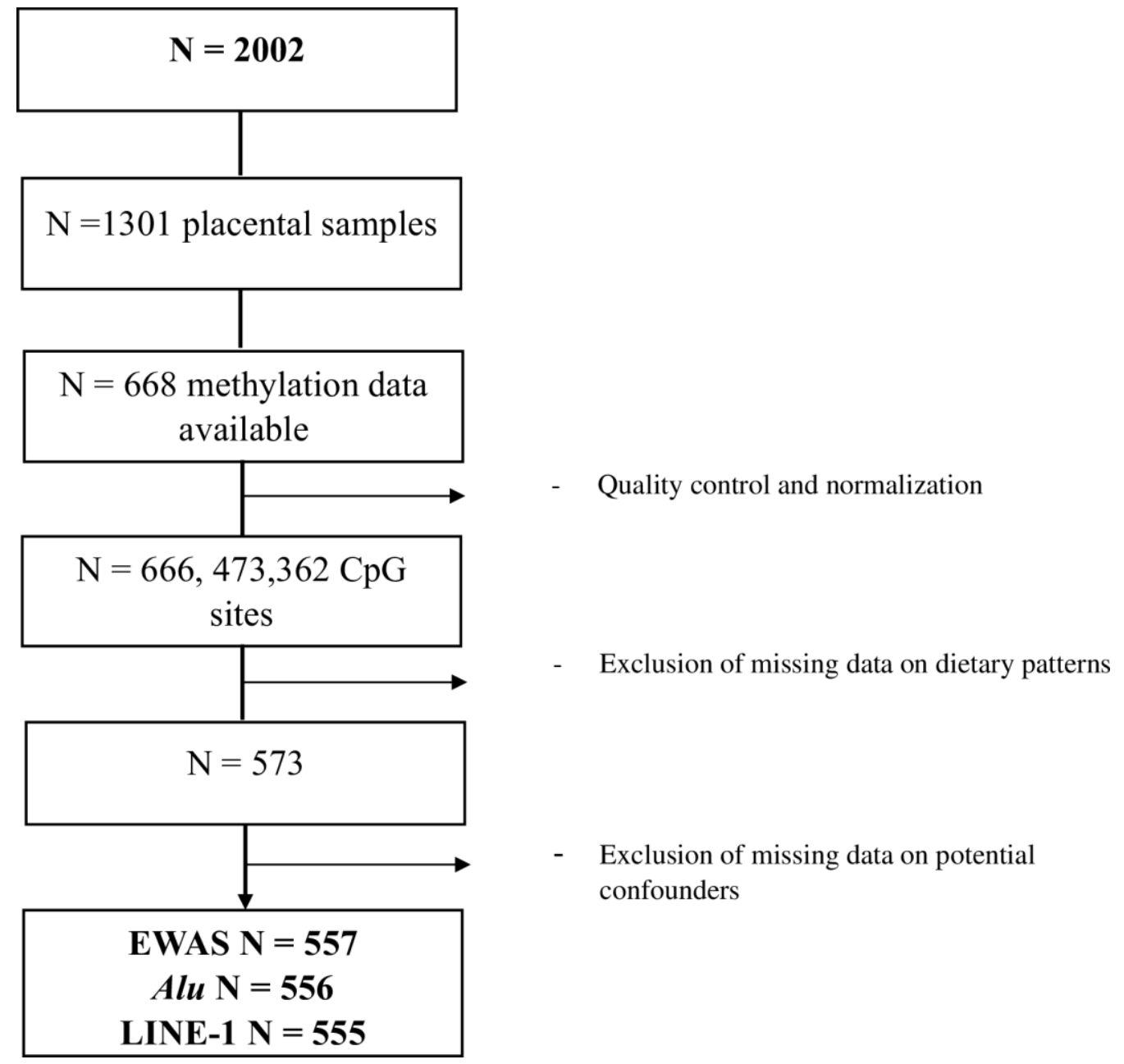

Figure 1: Flow-chart of population selection 


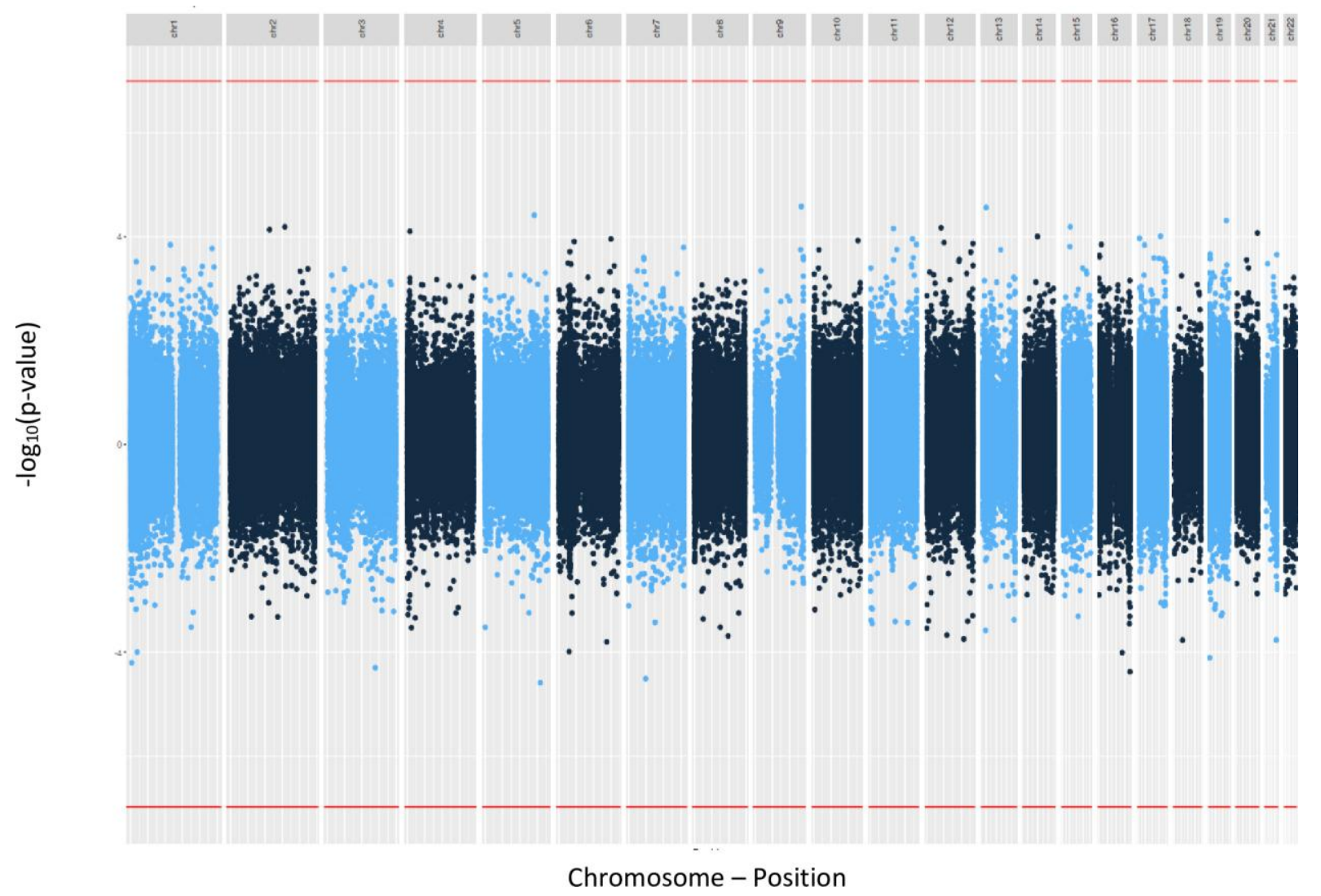

Figure 2: Manhattan plots of epigenome-wide association results for "varied and balanced pattern" within the placenta. The red dashed line represents Bonferroni correction significance threshold $\left(\mathrm{p}=1.0 \times 10^{-7}\right)$. The direction of the associations is reported with negative effects below zero and positive effects above zero.

Model adjusted for study center, maternal age, child sex, gestational age, smoking during pregnancy, batch effect, cellular composition and surrogate variable analysis variables. 


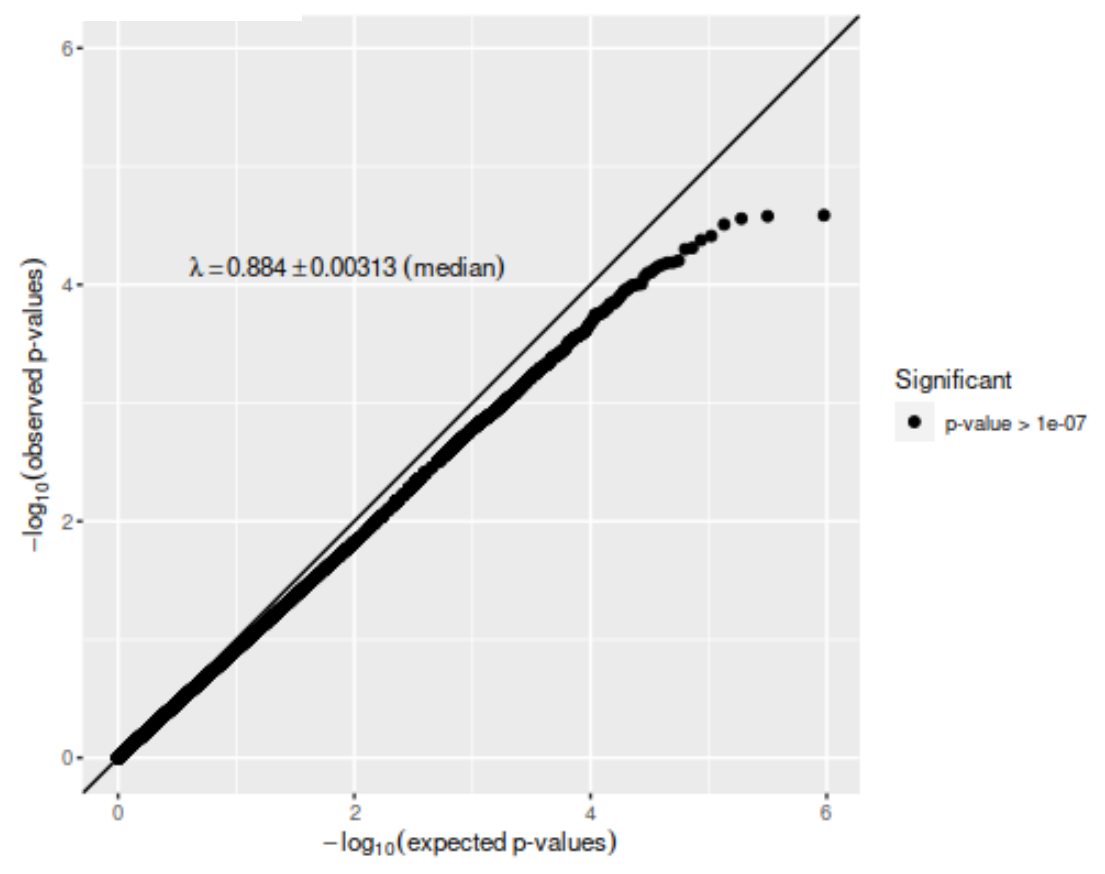

Figure 3: Quantile-quantile plot for regression model between scores on the "varied and balanced diet" in the year before pregnancy and placental DNA methylation.

Model adjusted for study center, maternal age, child sex, gestational age, smoking during pregnancy, batch effect, cellular composition, and SVA variables. 


\section{Supporting information}

Data availability

The EDEN individual-level data have restricted access owing to ethical and legal conditions in France. They are available upon request from the EDEN steering committee at etude.eden@inserm.fr and through collaborations with the principal investigators of EDEN. Questionnaires are also available upon request at the same address. 


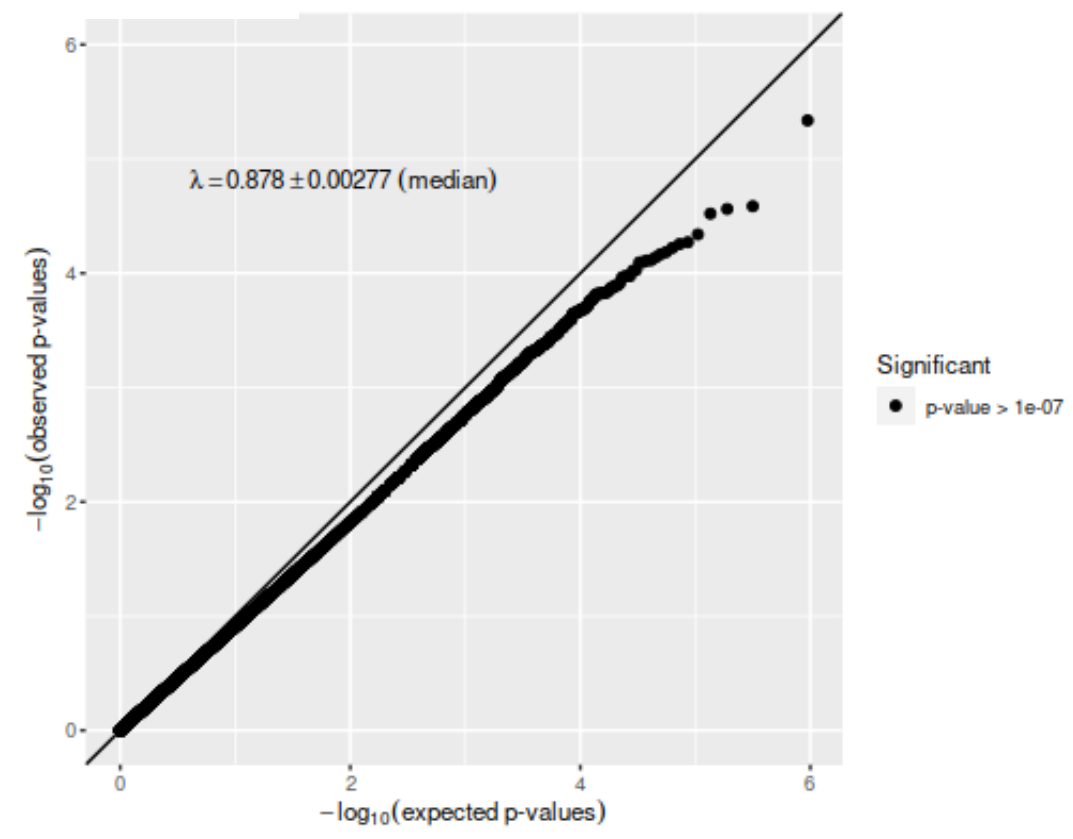

Supplemental Figure 1: Quantile-quantile (QQ) plot for regression model between scores on the "varied and balanced diet" pattern in the year before pregnancy and placental DNA methylation, additionally adjusted for vitamin supplementation.

Model adjusted for study center, maternal age, child sex, gestational age, smoking during pregnancy, batch effect, cellular composition, SVA variables and vitamin supplementation. 


\section{Vegetarian tendency pattern}

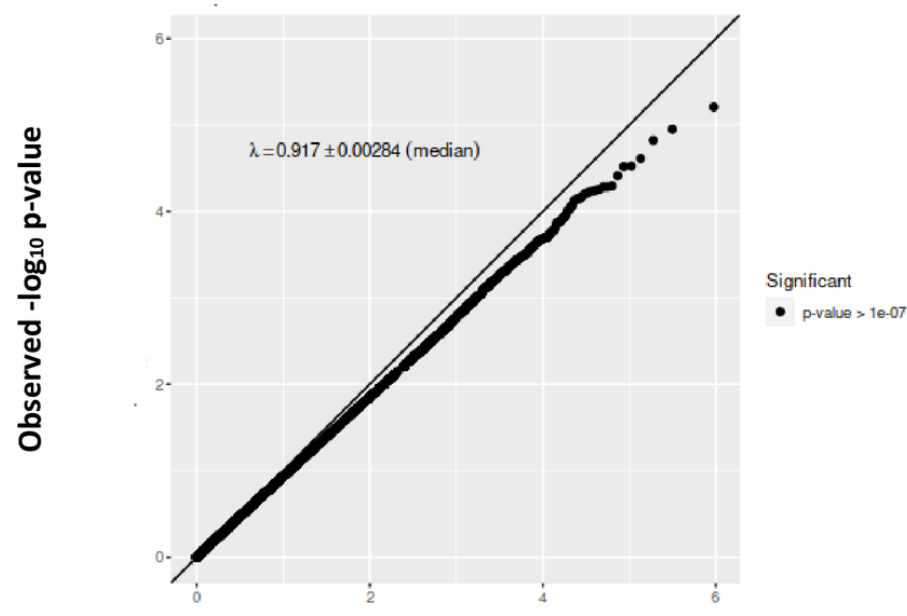

\section{Bread and starchy food pattern}

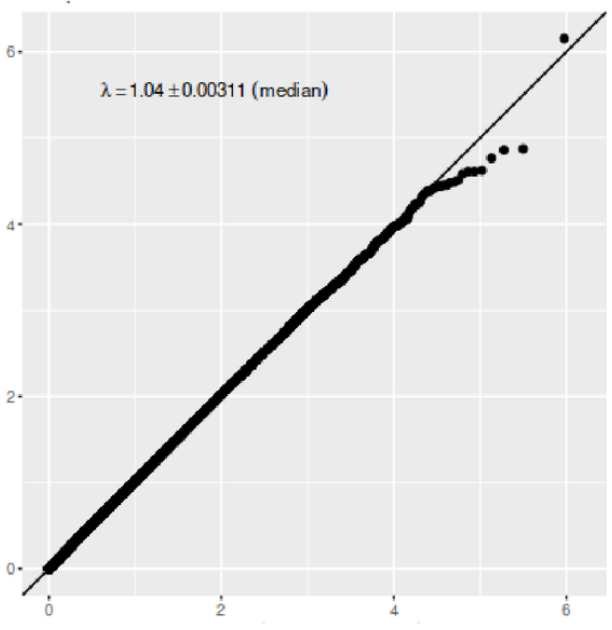

Vitamin supplementation

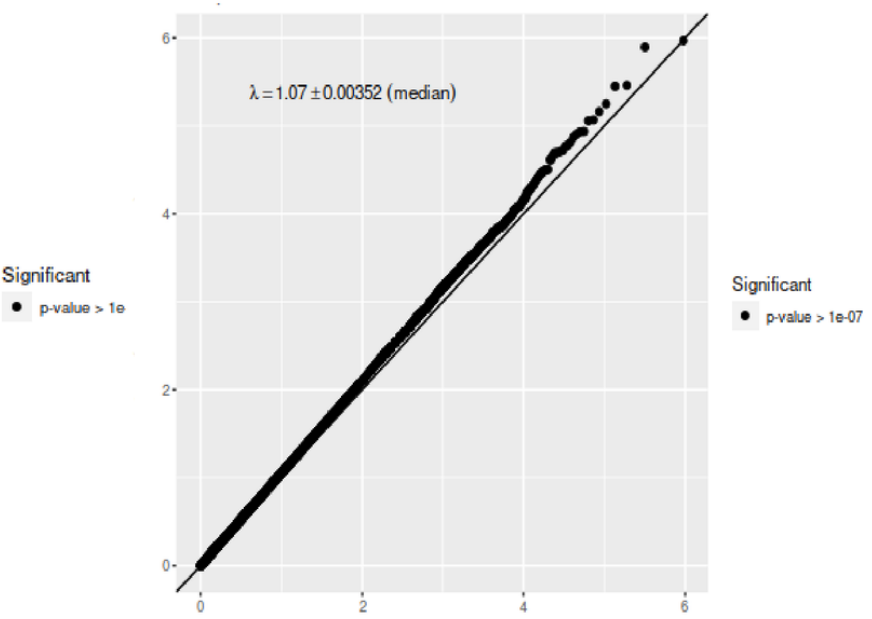

Expected $-\log _{10} \mathrm{p}$-value

Supplemental Figure 2: QQ plots for regression models between the "vegetarian tendency" or "bread and starchy food" patterns* in the year before pregnancy, vitamin supplementation** and placental DNA methylation.

* Model adjusted for study center, maternal age, child sex, gestational age, smoking during pregnancy, batch effect, cellular composition, surrogate variable analysis variables.

** Model adjusted for the previous factors and the three dietary patterns. 